Article

\title{
Improved Storage Properties and Cellular Uptake of Casticin-Loaded Nanoemulsions Stabilized by Whey Protein-Lactose Conjugate
}

\author{
Bei Zhang ${ }^{1}$, Miao Lei ${ }^{1}$, Wenjing Huang ${ }^{1}$, Gang Liu ${ }^{1}{ }^{\mathbb{C}}$, Fangcheng Jiang ${ }^{1,2}$, Dengfeng Peng ${ }^{3}$, \\ Qingrong Huang ${ }^{2, *}$ and Weiping Jin ${ }^{1, *}$ \\ 1 School of Food Science and Engineering, Wuhan Polytechnic University, Wuhan 430023, China; \\ B15827049116@163.com (B.Z.); 18707194179@163.com (M.L.); huangwenjingbest@163.com (W.H.); \\ lg820823@163.com (G.L.); fj109@scarletmail.rutgers.edu (F.J.) \\ 2 Department of Food Science, Rutgers University, New Brunswick, NJ 08901, USA \\ 3 Key Laboratory of Oilseeds Processing, Ministry of Agriculture, Oil Crops Research Institute, \\ Chinese Academy of Agricultural Science, Wuhan 430062, China; pengdengfeng@caas.cn \\ * Correspondence: qhuang@sebs.rutgers.edu (Q.H.); jwpfood@whpu.edu.cn (W.J.)
}

check for updates

Citation: Zhang, B.; Lei, M.; Huang, W.; Liu, G.; Jiang, F.; Peng, D.; Huang, Q.; Jin, W. Improved Storage Properties and Cellular Uptake of Casticin-Loaded Nanoemulsions Stabilized by Whey Protein-Lactose Conjugate. Foods 2021, 10, 1640. https://doi.org/10.3390/ foods 10071640

Academic Editor: Yan Li

Received: 22 June 2021

Accepted: 13 July 2021

Published: 15 July 2021

Publisher's Note: MDPI stays neutral with regard to jurisdictional claims in published maps and institutional affiliations.

Copyright: (c) 2021 by the authors. Licensee MDPI, Basel, Switzerland. This article is an open access article distributed under the terms and conditions of the Creative Commons Attribution (CC BY) license (https:// creativecommons.org/licenses/by/ $4.0 /)$

\begin{abstract}
Casticin has wide-ranging functional activities, but its water solubility is poor in food products. Here, a nanoemulsion stabilized by Maillard whey protein isolate conjugates (MWPI) was fabricated to encapsulate casticin. The nanoemulsion, with an average diameter of $200 \mathrm{~nm}$, possessed the capability to load $700 \mu \mathrm{g} / \mathrm{g}$ casticin. MWPI-stabilized nanoemulsion showed better stability than that of the WPI nanoemulsion during 4 weeks of storage. Both the inhibition effects of the casticin-loaded nanoemulsion on cancer cells and the process of cellular uptake were studied. Results revealed that the casticin-loaded nanoemulsion had better inhibitory activity in HepG2 and MCF-7 cells than free casticin. Cellular uptake of the nanoemulsion displayed a time-dependent manner. After the nanoemulsion passed into HepG2 and MCF-7 cells, it would locate in the lysosome but not in the nucleus. The main pathway for the nanoemulsion to enter HepG2 cells was pinocytosis, whereas, it entered MCF-7 predominantly through the clathrin-mediated pit. This work implies that MWPI-stabilized nanoemulsions could be utilized as an effective delivery system to load casticin and have the potential to be applied in the food and pharmaceutical industries.
\end{abstract}

Keywords: casticin; nanoemulsion; whey protein isolated; conjugate; cellular uptake

\section{Introduction}

Casticin, 5,3'-dihydroxy-3,6,7,4-tetramthoxyflavone, is a kind of polymethoxy-flavonoid (PMF) extracted from the traditional Chinese medicine Vitex (Fructus Vititcis) [1]. Numerous studies have demonstrated that casticin has potential functional activities, including antiinflammatory [2], anti-hyperprolactinemia [3], and anti-cancer [4]. Ramchandani et al. found that casticin significantly inhibited the proliferation of oral, lung, hepatocellular carcinoma, cervical, and bladder cancer cells. [5] One molecule of casticin contains four methoxy groups that are connected to the flavone ring. This structure possesses a strong planar structure that resists the entry of water [6]. The poor water-solubility of casticin decreases its bioavailability and limits its application in designing functional foods.

The fabrication of an emulsion is a potential way to encapsulate the poorly watersoluble PMFs and improve their bioavailability. Because hydrophobic bioactive compounds are easy to dissolve in the oil phase, they can be kinetically stable dispersed into the aqueous phase after forming nanoemulsions. Due to the small size (20-200 nm), nanoemulsions have the advantages of a large specific surface area, high stability, and adjustable rheology properties $[7,8]$. When the hydrophobic bioactive compounds are encapsulated in the nanoemulsion, they can be accurately delivered to a specific location in vivo, thereby enhancing their physical stability, reducing side effects, and improving bioavailability 
at the same time $[9,10]$. Many research papers have reported nanoemulsions as good delivery systems for improving the biological activity of PMFs [11,12]. Lei et al. fabricated a nanoemulsion to encapsulate nobiletin and immobilized it in an alginate hydrogel. Results showed that the nanoemulsion controlled the release of nobiletin and improved its stability during digestion and storage [13]. Soy protein isolate-stabilized nanoemulsions encapsulated the supersaturated tangeretin, and, with the addition of glycerin, the high loading of tangeretin was maintained and stabilized [14].

Glycosylate-modified protein, mainly through the Maillard reaction, possesses suitable amphiphilicity, which can provide steric hindrance to prevent the aggregation and disproportionation of emulsion droplets [15]. Mengíbar et al. evaluated the emulsifying ability of chitosan and $\beta$-lactoglobulin conjugates developed through the Maillard reaction, and the results showed that high-molecular-weight chitosan (56 and $39 \mathrm{kDa}$ )- $\beta$-lactoglobulin conjugates had better emulsifying ability than unreacted protein [16]. Nagaraju et al. found that nanoemulsions stabilized by Maillard conjugates formed by sodium caseinate and polysaccharides (maltodextrin and pectin) had higher stability than that of nanoemulsions prepared by protein or polysaccharide separately [17]. WPI is commonly considered a high-quality protein supplement, though its stability is easily affected by temperature and $\mathrm{pH}$ [18]. Wang et al. fabricated WPI-inulin to improve the functional properties of WPI near its $\mathrm{pI}$ [19]. Xu et al. prepared a WPI-beet pectin conjugate-stabilized $\beta$-carotene emulsion and found it improved the centrifugal transmission profile and the freeze-thaw stability of the emulsion [20].

In the current work, the Maillard whey protein isolate-lactose conjugate (MWPI) was prepared and utilized as an emulsifier to improve the stability of the nanoemulsion. Casticin was loaded in the MWPI-stabilized nanoemulsion to inhibit the growth of MCF-7 and HepG2 cancer cells. Finally, the kinetics and mechanism of the cellular uptake of nanoemulsion were preliminarily clarified.

\section{Material and Methods}

\subsection{Materials and Chemicals}

The whey protein isolate (WPI) was gifted from Hilmar, USA. The casticin was extracted from Vitex, and the purity was $94.6 \%$ after comparison with a standard by HPLC. The casticin standard ( $\geq 98 \%$, V117963), L-lactose, and dimethyl sulfoxide (biochemical grade, $\geq 99.7 \%$ ) were purchased from Aladdin Reagent Co., Ltd. (Shanghai, China). The MCF-7 and HepG2 cell lines were obtained from the China Center for Type Culture Collection (CTCC, Wuhan, Hubei, China). Fetal bovine serum (FBS) and Dulbecco's modified eagle's medium (DMEM) for cell culture were purchased from Gibco (Grand Island, NE, USA). Penicillin-streptomycin and $0.25 \%$ trypsin were obtained from Jinuo Biomedical Technology Co., Ltd. (Hangzhou, China). Phosphate buffer saline (PBS) was purchased from Hyclone (Logan City, UT, USA). Cell-culture flasks with a capacity of $25 \mathrm{~cm}^{2}, 96-$ well cell-culture plates, and cryotubes were purchased from Corning Co., Ltd. (Shanghai, China). Nile red and coumarin-6 were purchased from Aladdin Reagent Co., Ltd. (Shanghai, China). Lyso-Tracker red (a lysosomal red fluorescent probe) and 4,6-diamino-2-phenyl indole (DAPI) were purchased from Beyotime Biotechnology Co., Ltd. (Shanghai, China) and Solarbio Technology Co., Ltd. (Beijing, China), respectively.

\subsection{Preparation and Characterization of WPI-Lactose Maillard Conjugate}

\subsubsection{Preparation of WPI-Lactose Maillard Conjugate (MWPI)}

WPI-lactose Maillard conjugate was fabricated according to the method reported by Liu et al. with some modifications [21,22]. Briefly, the powders of WPI and lactose were dissolved in DI water together with a ratio of 1:2 (w/w), and the final solid content was $5-10 \%$. The mixture solution was adjusted to $\mathrm{pH} 7.0$ and stirred for $12 \mathrm{~h}$. After the solution was freeze-dried, the powders were placed in a desiccator with saturated $\mathrm{KBr}$ (relative humidity $79 \%$ ). The WPI-lactose Maillard conjugates were obtained after reacting at $70{ }^{\circ} \mathrm{C}$ for $24 \mathrm{~h}$. 


\subsubsection{Fourier Transform Infrared Spectroscopy (FTIR) Analysis}

The powders of WPI and WPI-lactose Maillard conjugates were mixed with $\mathrm{KBr}$ separately, and then they were pressed into thin slices. The FTIR spectra of powders were measured with a NEXUS670 spectrometer (Nikolai Instruments Inc., Potwin, KS, USA). The wavenumber ranged from 4000 to $400 \mathrm{~cm}^{-1}$. The resolution and the number of scans were $4 \mathrm{~cm}^{-1}$ and 32 , respectively.

\subsubsection{Sodium Dodecyl Sulfate Polyacrylamide Gel Electrophoresis (SDS-PAGE)}

The sample $(2 \mathrm{mg} / \mathrm{mL})$ of WPI and MWPI were diluted 5 times with the loading buffer, centrifuged at $6000 \mathrm{rpm}$ for $5 \mathrm{~min}$, and then boiled for $5 \mathrm{~min}$ to complete denaturation. According to the protocol of the SDS-PAGE kit (Beyotime Biotechnology, Shanghai, China), the $12 \%$ separating gel and $5 \%$ concentrated gel were used for separation. Operation proceeded at $60 \mathrm{~V}$ for the first $30 \mathrm{~min}$, and then changed to $120 \mathrm{~V}$. Then, the gel was stained with $0.25 \%$ Coomassie Brilliant Blue R-250 for $30 \mathrm{~min}$, and de-stained. An image was obtained using a Bio-Rad scanner (Hercules, CA, USA).

\subsection{Preparation and Characterization of MWPI-Stabilized Nanoemulsions}

\subsubsection{Preparation of the WPI/MWPI-Stabilized Nanoemulsion}

The WPI or MWPI powder was dissolved in $10 \mathrm{mM}$ PBS (pH 7.4) at a concentration of $1.0 \mathrm{wt} \%$, and the oil phase fraction was set at $10 \%$. The MWPI-stabilized nanoemulsion was fabricated via high-speed homogenization (Ultra-turrax T18IKA, GmbH, Berlin, Germany) at 10,000 rpm for $10 \mathrm{~min}$, and a high-pressure homogenization (AH-2010, ATS Industrial Systems, GmbH, Berlin, Germany) with 900 Mbar and 10 cycles in succession.

\subsubsection{Storage Stability Test}

Nanoemulsions stabilized by WPI and MWPI were placed at $4{ }^{\circ} \mathrm{C}$, and $0.02 \%$ sodium azide was added in emulsions to prevent bacteria growth. The particle size of nanoemulsions measured by Zetasizer Nano-ZS (Malvern, UK) at 1 week, 2 weeks, and 4 weeks was recorded as the indicator for evaluating storage stability.

\subsection{Fabrication of Casticin-Loaded Nanoemulsions}

\subsubsection{The Solubility of Casticin in Oil}

An excess of casticin was added to $10 \mathrm{~g}$ medium chain triglyceride (MCT), and magnetically stirred overnight at room temperature. After centrifugation at $5000 \times g$ for $15 \mathrm{~min}, 200 \mu \mathrm{L}$ of the supernatant was mixed with $800 \mu \mathrm{L}$ methanol and then filtered through a $0.45 \mu \mathrm{m}$ filter for high performance liquid chromatography (HPLC) analysis. The samples $(20 \mu \mathrm{L})$ were analyzed by a reverse-phase C18 column $(150 \mu \mathrm{m} \times 4.6 \mu \mathrm{m}$, Shim-pack VP-ODS C18 column, Japan) with buffer A (ultrapure water) and buffer B (acetonitrile) at a flow rate of $1 \mathrm{~mL} / \mathrm{min}$. The detection wavelength was $254 \mathrm{~nm}$. The gradient elution method was as follows: from $40 \%$ to $55 \%$ buffer B for $10 \mathrm{~min}$, from $55 \%$ to $70 \%$ buffer B for $5 \mathrm{~min}$, from $70 \%$ to $80 \%$ buffer B for $5 \mathrm{~min}$, and held at $40 \%$ buffer B for $10 \mathrm{~min}$.

\subsubsection{Preparation of Casticin-Loaded Nanoemulsion}

The CAS was dissolved in MCT in a saturated state as an oil phase. The water phase was a $1.0 \mathrm{wt} \%$ MWPI solution. The homogenization process was carried out as described in Section 2.3.1.

\subsubsection{Spray Drying of the Casticin-Loaded Nanoemulsion}

The MWPI-stabilized nanoemulsion was spray dried under the following conditions: inlet air temperature $115^{\circ} \mathrm{C}$, feed rate $14 \mathrm{~mL} / \mathrm{min}$, spray airflow $1000 \mathrm{~L} / \mathrm{h}$, and needle frequency 1 time $/ 15 \mathrm{~s}$. Finally, the obtained powder was kept in a sealed bag protected from light, at $4{ }^{\circ} \mathrm{C}$. 


\subsubsection{Determination of Casticin Content in Nanoemulsion}

The casticin in the nanoemulsion was extracted by adding $1 \mathrm{~mL}$ of n-hexane to $1 \mathrm{~g}$ of nanoemulsion, followed by vortexing and centrifugation at $10,000 \times \mathrm{g}$ for $10 \mathrm{~min}$. Next, the content of casticin was analyzed using HPLC as described in Section 2.4.1.

\subsubsection{Stability of Casticin-Loaded Nanoemulsion in the Culture Medium}

The nanoemulsion was diluted 10-fold with DMEM (for cell culture, without FBS) and stored at $37^{\circ} \mathrm{C}$ for $24 \mathrm{~h}$. The particle size and polydispersity (PDI) of the nanoemulsion were recorded using a Marlven Nanosizer ZS90 (Marlven, UK).

\subsection{Inhibitor Effects of Casticin-Loaded Nanoemulsion on Cancer Cells}

MTT (3-(4,5-Dimethylthiazol-2-yl)-2,5-diphenyltetrazolium bromide) was used to evaluate the ability of the nanoemulsion to inhibit the proliferation of MCF-7 and HepG2 cells. Briefly, cells were seeded on 96-well plates in the exponential growth phase, and then the nanoemulsion was diluted with DMEM to control the final concentrations of casticin. After incubation, the nanoemulsion was removed, and each well was washed with PBS 2 3 times. Finally, $100 \mu \mathrm{L}$ DMEM and $10 \mu \mathrm{L}$ MTT solution were added to the wells and incubated for $4 \mathrm{~h}$. Then, the medium was removed and $150 \mu \mathrm{L}$ DMSO/well was added to dissolve the formazan crystals. The absorbance at $570 \mathrm{~nm}$ was recorded on a microplate reader (iMark, BIO-RAD, Hercules, CA, UAS). Untreated cells were defined as the negative control, and their OD value was recorded as $100 \%$ survival.

$$
\text { Inhibition rate }=\left(1-\mathrm{OD}_{\text {sample }} / \mathrm{OD}_{\text {control }}\right) \times 100 \%
$$

\subsection{Cellular Uptake of the Casticin-Loaded Nanoemulsion}

First, Nile red was added in the MCT as the fluorescence dye before preparing the nanoemulsion. Then, $1 \mathrm{~mL}$ of cell suspension $\left(2 \times 10^{4}\right.$ cells $\left./ \mathrm{mL}\right)$ was inoculated into the CLSM dish and cultured for $24 \mathrm{~h}\left(37^{\circ} \mathrm{C}\right.$ and $\left.5 \% \mathrm{CO}_{2}\right)$. After removing the medium and washing the cell surface with PBS, the casticin-loaded nanoemulsion labeled with Nile red was added and cultured for $10 \mathrm{~min}, 20 \mathrm{~min}, 30 \mathrm{~min}, 1 \mathrm{~h}$, and $2 \mathrm{~h}$. Before CLSM observation, the nanoemulsion was removed and the cells were washed three times by PBS buffer. The nuclei were stained with DAPI for $15 \mathrm{~min}$.

\subsection{Localization of Casticin-Loaded Nanoemulsion in Cells}

Because lysosomes were dyed using LysoTracker red, the oil phase in the nanoemulsion was dyed with coumarin-6, which is a type of green fluorescence dye. The operation of the cell culture was similar to the description in Section 2.5. The coumarin 6-labeled nanoemulsion was added and incubated for $20 \mathrm{~min}$. The cell surface was washed three times with PBS and fixed with $4 \%$ paraformaldehyde for $30 \mathrm{~min}$. After washing with PBS three times, LysoTracker Red was used to label the lysosomes for $1 \mathrm{~h}$. Before CLSM observation, cells were washed three times with PBS, and the nuclei were labeled with $100 \mu \mathrm{L}$ DAPI for $15 \mathrm{~min}$.

\subsection{Cellular Uptake Mechanism of Casticin-Loaded Nanoemulsion}

MCF-7 and HepG2 cells were inoculated into a CLSM dish as described in Section 2.5. To study the effect of temperature and inhibitors on the cellular uptake of the nanoemulsion, cells were pretreated at $4{ }^{\circ} \mathrm{C}$ or by adding $25 \mu \mathrm{g} / \mathrm{mL}$ dynasore, $10 \mu \mathrm{g} / \mathrm{mL}$ chlorpromazine, and $15 \mu \mathrm{g} / \mathrm{mL}$ amiloride $\mathrm{HCl}$ dihydrate for $30 \mathrm{~min}$, respectively. Then, the coumarin 6-labeled nanoemulsion was incubated with the cells for $20 \mathrm{~min}$. The surface of the cells was washed three times with PBS and observed under a CLSM.

\subsection{Statistical Analysis}

Each measurement of the samples was repeated at least three times, and the data was expressed as the average values and standard error in figures. The data were analyzed by 
SPSS 23 (SPSS Inc., Chicago, IL, USA) via one-way ANOVA. The significance level was $p<0.05$, and figures were drawn with Origin 2017 (Origin Lab., Northampton, MA, USA).

\section{Results and Discussion}

\subsection{Characterization of MWPI}

The FTIR spectra of WPI and MWPI are shown in Figure 1a. The main characteristic peaks of WPI were $3290 \mathrm{~cm}^{-1}$ (N-H stretching and hydrogen bonding), $1640 \mathrm{~cm}^{-1}$ (amide I band, $\mathrm{C}=\mathrm{O}$ stretching), $1540 \mathrm{~cm}^{-1}$ (amide II band, $\mathrm{N}-\mathrm{H}$ bending), and $1390 \mathrm{~cm}^{-1}$ (amide III band, C-N expansion) [23,24]. As for MWPI, the absorption peak at $3290 \mathrm{~cm}^{-1}$ was shifted to $3390 \mathrm{~cm}^{-1}$, which might be ascribed to the stretching vibration of free-OH or the deformation vibration of the $\mathrm{N}-\mathrm{H}$ bond. The peak at $1640 \mathrm{~cm}^{-1}$ is derived from the $\alpha$-helix or random coil structure. After modification, the peak of WPI at $1640 \mathrm{~cm}^{-1}$ was shifted to $1660 \mathrm{~cm}^{-1}$, indicating that the $\alpha$-helix or random coil structure had been changed. Compared with WPI, MWPI had a new absorption peak at $1000-1260 \mathrm{~cm}^{-1}$, which might be attributed to the stretching vibration of the C-O bond, resulting from the presence of multiple hydroxyl groups on the sugar chain. Figure $1 \mathrm{~b}$ shows the SDS-PAGE of MWPI and WPI. The WPI mainly displayed a main band of $15 \mathrm{kDa}$ and $35 \mathrm{kDa}$, which corresponded to $\beta$-lactoglobulin and dimers of $\beta$-lactoglobulin. After glycosylation, the molecular weight of the protein increased to $19 \mathrm{kDa}$ and $40 \mathrm{kDa}$. It implied that WPI was successfully combined with lactose through Maillard reaction.

(a)

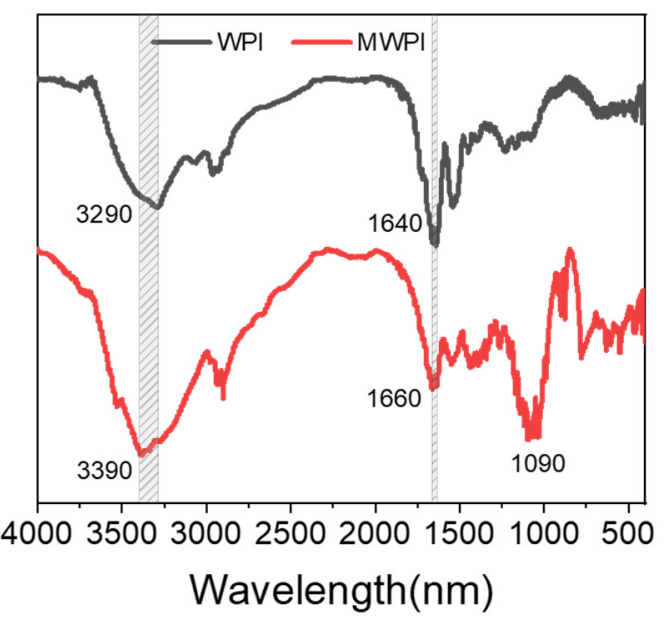

(b)

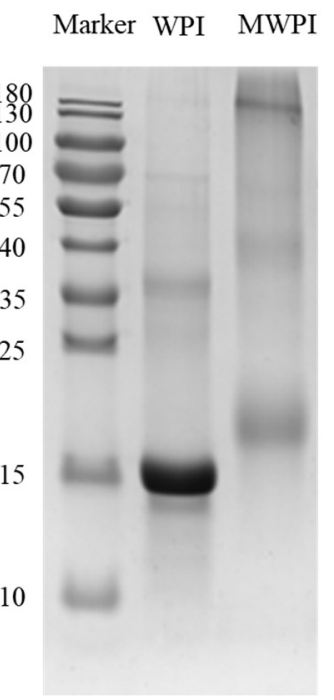

Figure 1. FTIR spectra (a) and SDS-PAGE (b) of WPI and MWPI.

\subsection{Storage Stability of WPI and MWPI-Stabilized Nanoemulsions}

Figure 2a shows changes of particle size in nanoemulsion stabilized by WPI and MWPI during the storage. The particle size of the freshly prepared WPI and MWPI nanoemulsions was $180 \mathrm{~nm}$ and $200 \mathrm{~nm}$, respectively. As the storage time increased, the particle size of the WPI-stabilized nanoemulsion increased significantly. However, the particle size of the nanoemulsion stabilized by MWPI remained at around $250 \mathrm{~nm}$ after storage for 4 weeks. The accordant changes in the visual appearance of the nanoemulsions were clearly observed (Figure $2 \mathrm{~b}$ ). In the 4 th week, the WPI-stabilized nanoemulsion began to cream, while the MWPI-stabilized nanoemulsion did not obviously change. This implied that MWPI had better emulsion storage stability than WPI. The Maillard reaction is a non-enzymatic reaction that forms covalent bonds between proteins and polysaccharides. The hydrophobic groups of proteins are anchored on the oil droplet surfaces, while the hydrophilic chains of polysaccharides generate a strong steric repulsion between oil droplets. 


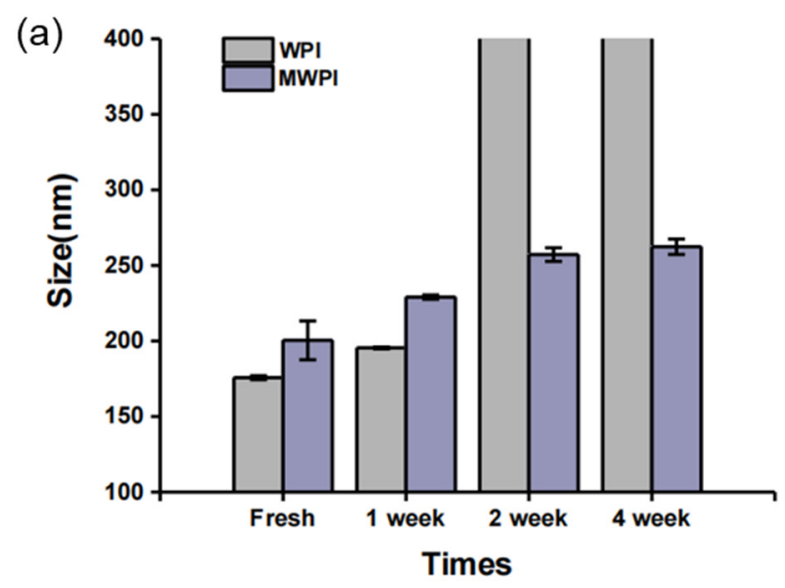

(b)

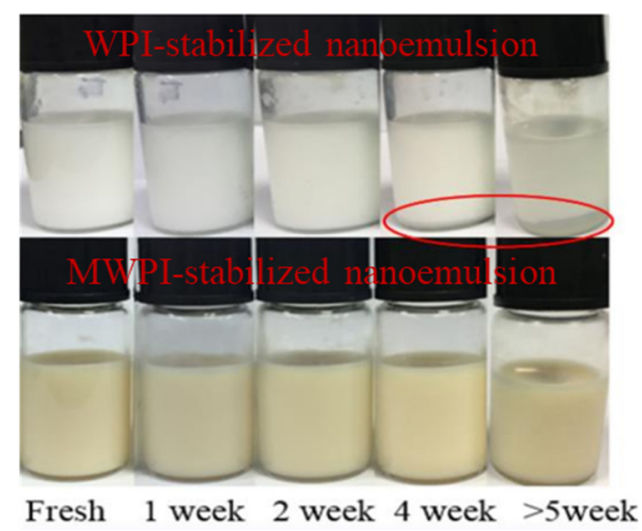

Figure 2. The particle size diagram (a) and appearance diagram (b) of nanoemulsions prepared with WPI and MWPI as emulsifiers over time.

\subsection{Characteristics of Casticin-Loaded Nanoemulsion}

The solubility of casticin in MCT was $2.05 \mathrm{mM}$. MCT is a medium-chain fatty acid with low viscosity, high transparency, and good compatibility and is widely applied in the pharmaceutical, cosmetic, and food industries. The casticin-saturated MCT and whey protein isolate-lactose conjugate were chosen to fabricate the nanoemulsion via high-speed homogenization and high-pressure homogenization, and then the nanoemulsion was spraydried. According to HPLC analysis, the casticin content in the spray-dried casticin-loaded nanoemulsion powder was $700 \mu \mathrm{g} / \mathrm{g}$.

The stability of the casticin-loaded nanoemulsion in DMEM medium was characterized by evaluating the particle size. Figure 3 shows the particle size of the casticin-loaded nanoemulsion after adding it into DMEM. At the beginning of the reaction, the particle size of the nanoparticles was about $200 \mathrm{~nm}$, and there was no significant change from the blank group, indicating that casticin did not change the particle size of the casticin-loaded nanoemulsion. Over $24 \mathrm{~h}$, the particle size of the casticin-loaded nanoemulsion did not change significantly, and the PDI was also less than 0.3 , indicating that the emulsion had good stability and uniform dispersion. In summary, the casticin-loaded nanoemulsion maintained an unchanged particle size and PDI over $24 \mathrm{~h}$. 


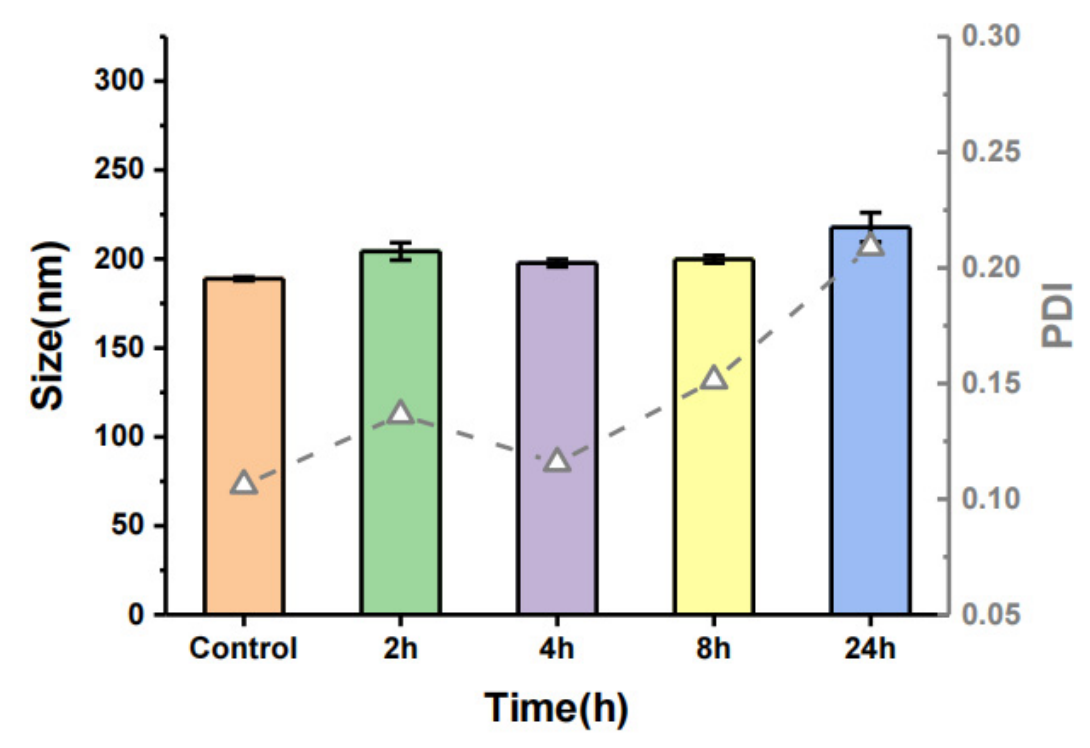

Figure 3. Particle size and PDI of CAS-NEs in the cell culture medium (DMEM) within $24 \mathrm{~h}$; the particle size is represented by bars and PDI by lines.

\subsection{Cell Anticancer Activity of the Casticin-Loaded Nanoemulsion}

Because liver cancer and breast cancer are among the cancers with the highest incidence in China and in women in the world, respectively, the typical cell lines of Hep G2 and MCF-7 cell lines of the two were chosen as models. The inhibitory effect of casticin on HepG2 and MCF-7 and the cellular uptake mechanism might provide preliminary directions for cancer treatment. The anti-cancer activity of the blank emulsion, free casticin, and casticin-loaded nanoemulsion on MCF-7 and HepG2 cells was measured by the MTT test. The relationship between the dosage of casticin and cell viability is shown in Figure 4 . The blank nanoemulsion showed very low cytotoxicity. The cell survival rate in MCF-7 cells was about $90 \%$ and was almost $100 \%$ in HepG2 cells. Therefore, the whey protein isolate-lactose conjugate-stabilized nanoemulsion could be considered a safe drug-delivery vehicle. Over $24 \mathrm{~h}$, as the concentration of free casticin increased to $100 \mu \mathrm{g} / \mathrm{mL}$, there was a significant inhibitory effect on MCF-7 cells, whereas $50 \mu \mathrm{g} / \mathrm{mL}$ free casticin significantly inhibited the HepG2 cells. Compared with free casticin, when the concentration of casticin in the nanoemulsion reached $25 \mu \mathrm{g} / \mathrm{mL}$, the inhibitory effect on MCF-7 and HepG2 cells was obvious. After $48 \mathrm{~h}$, the inhibitory effect of the casticin-loaded nanoemulsion on cells was significantly higher than that of free casticin. The casticin-loaded nanoemulsion has a nanometer particle size, which allows it to enter cells through endocytosis and release casticin in the endosomes and lysosomes over a long period of time. The controlledrelease of bioactive compounds from a nano-carrier can greatly improve the efficacy of the encapsulated substance [25]. 
(a)

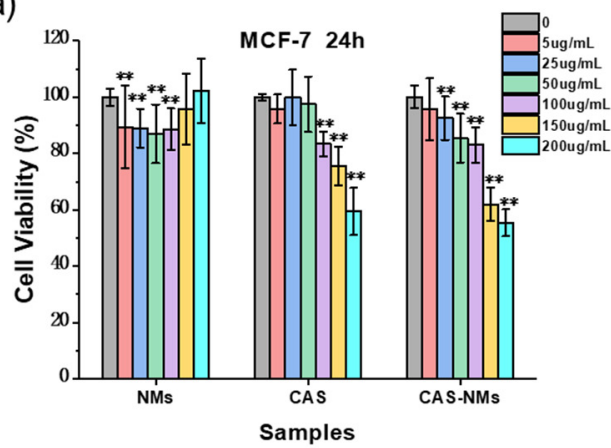

(c)

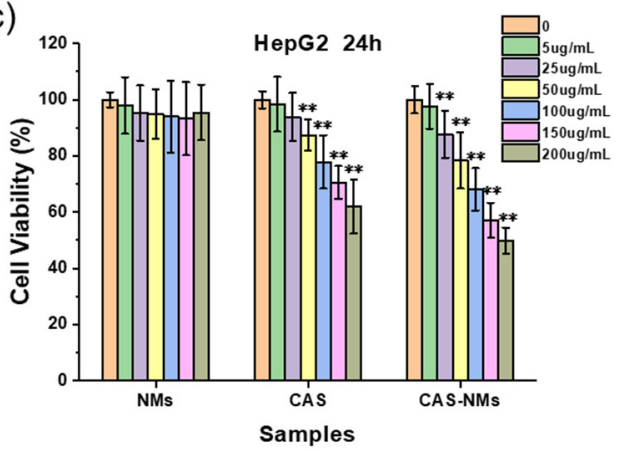

(b)

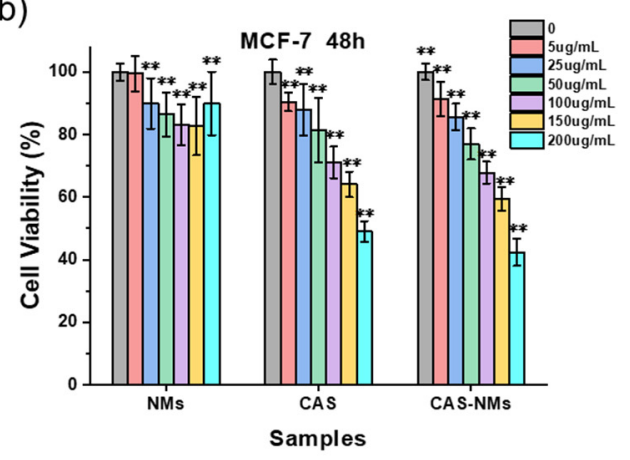

(d)

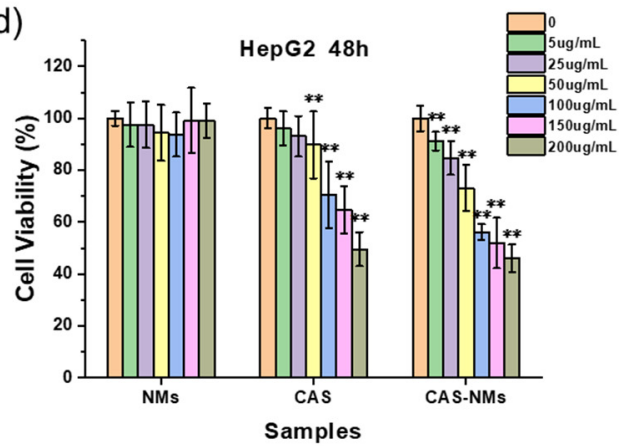

Figure 4. Cell viability of MCF-7 (a,b) and HepG2 (c,d) incubated with blank nanoemulsions (NMs), free casticin (CAS), and CAS-loaded nanoemulsions (CAS-NMs) for $24 \mathrm{~h}$ and $48 \mathrm{~h}$ respectively, which ** means $p<0.01$ as compared to the control group.

\subsection{Cellular Uptake of the Casticin-Loaded Nanoemulsions}

The uptake of the casticin-loaded nanoemulsion in the MCF-7 and HepG2 cells observed by CLSM is shown in Figures 5 and 6, respectively. The casticin-loaded nanoemulsion was labeled with Nile red, and the nuclei were stained with DAPI. After culturing the MCF-7 cells with the casticin-loaded nanoemulsion, a small amount of red fluorescence appeared dispersed in the lysosome of the cells after $5 \mathrm{~min}$. The intensity of the red fluorescence in the cells was significantly enhanced after $20 \mathrm{~min}$, which meant that the MCF-7 cells were continuously taking up the casticin-loaded nanoemulsion in a time-dependent manner. The red fluorescence in the MCF-7 cells gradually became weak and disappeared completely after $2 \mathrm{~h}$. Peng et al. found that nanoparticles were easily absorbed by cells if their size was less than $200 \mathrm{~nm}$ [26]. Because the average particle size of the casticin-loaded nanoemulsion was $180 \mathrm{~nm}$, one possible reason for the gradual disappearance of fluorescence could be related to the decomposition of the casticin-loaded nanoemulsion over a prolonged period of time. Additionally, the areas of red and blue fluorescence did not overlap, suggesting that the casticin-loaded nanoemulsion did not enter the nucleus but stayed in the cytoplasm. The cellular uptake phenomenon in the HepG2 cells was similar to that of the MCF-7 cells, but the optimized uptake time was $30 \mathrm{~min}$.

To clarify the mechanism of the inhibition of cancer cells by the casticin-loaded nanoemulsion, the determination of cell localization was carried out. The casticin-loaded nanoemulsion was labeled with coumarin-6 (green color); the cell nuclei were dyed with DAPI (blue color), and the lysosomes were labeled with LysoTracker red. As shown in Figure 7, the casticin-loaded nanoemulsion was distributed in the cell cytoplasm after entering the cell. The merged view shows that the red fluorescence of the lysosome is overlapped by the green fluorescence of the casticin-loaded nanoemulsion, while the blue fluorescence of the nucleus is distinct. This indicated that the casticin-loaded nanoemulsion entered the lysosome after cellular uptake but did not enter the nucleus. Many studies have shown that nanomaterials enter cells through endocytosis to form endosomes and then are accumulated in lysosomes [27]. Kam et al. labeled single-walled carbon nanotubes (SWNT) and co-cultured them with HL60 cells. They found that SWNTs were distributed in the 
cytoplasm, and mainly concentrated in the lysosomes rather than entering the nucleus [28]. The cell recognized the nanomaterials as alien invaders and then transported them to the lysosome for degradation [29].

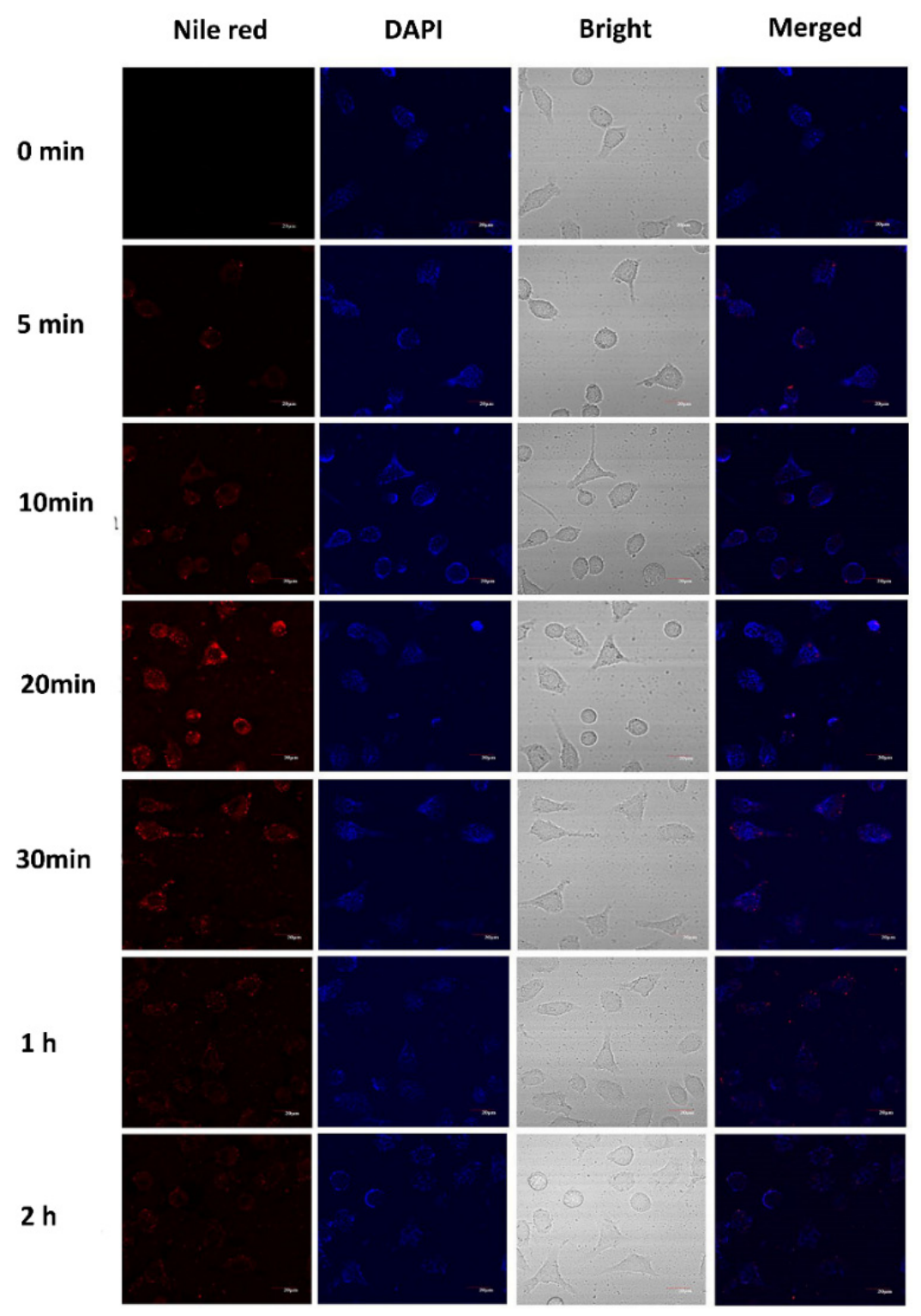

Figure 5. Cellular uptake observed by CLSM of cultured MCF-7 after treatment with CAS-loaded nanoemulsions. Cell nuclei were stained with DAPI for visualization in blue, and nanoemulsions were dyed with Nile red in red. 


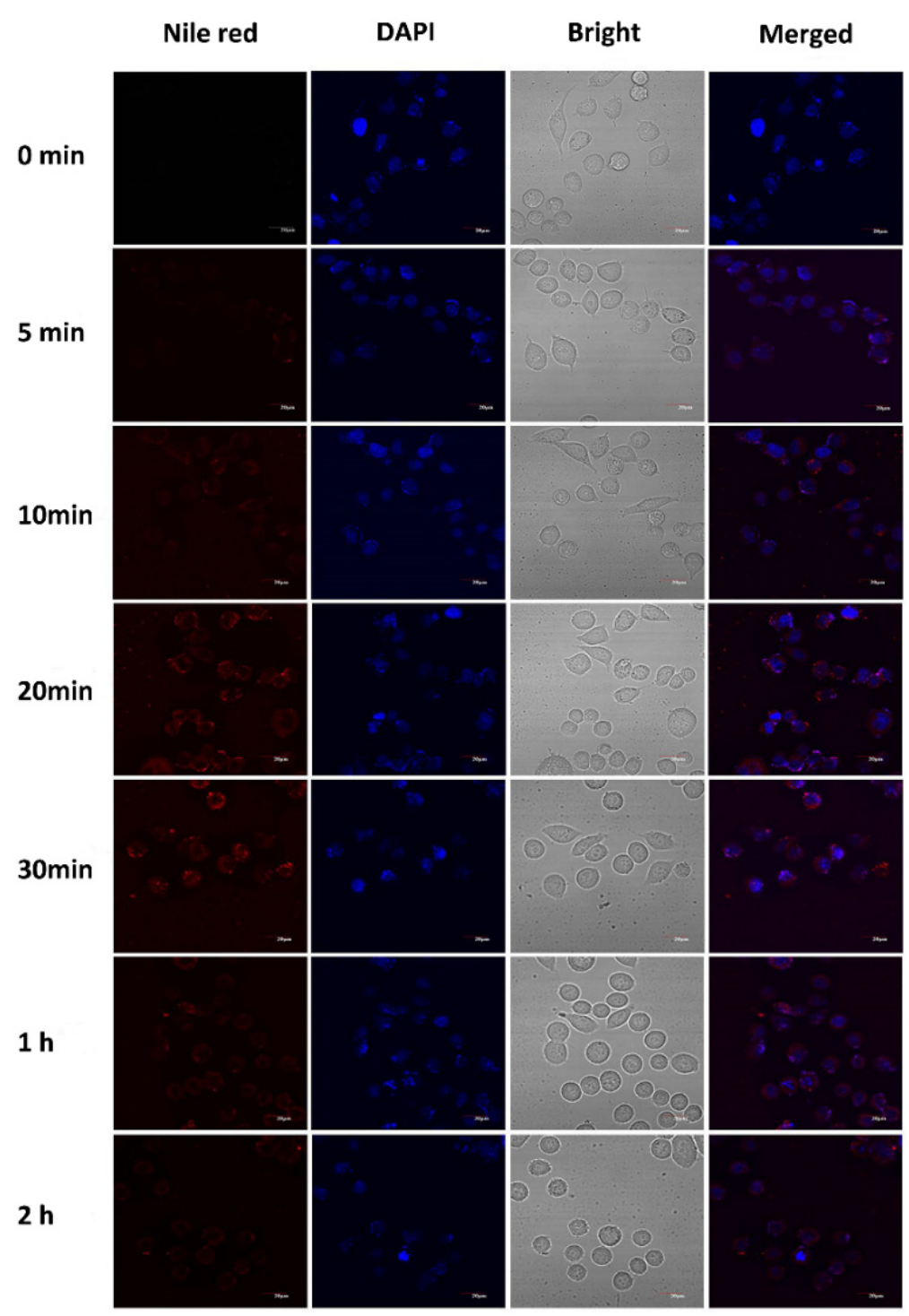

Figure 6. Cellular uptake observed by CLSM of cultured HepG2 after treatment with CAS-loaded nanoemulsions. Cell nuclei were stained with DAPI for visualization in blue, and nanoemulsions were dyed with Nile red in red.

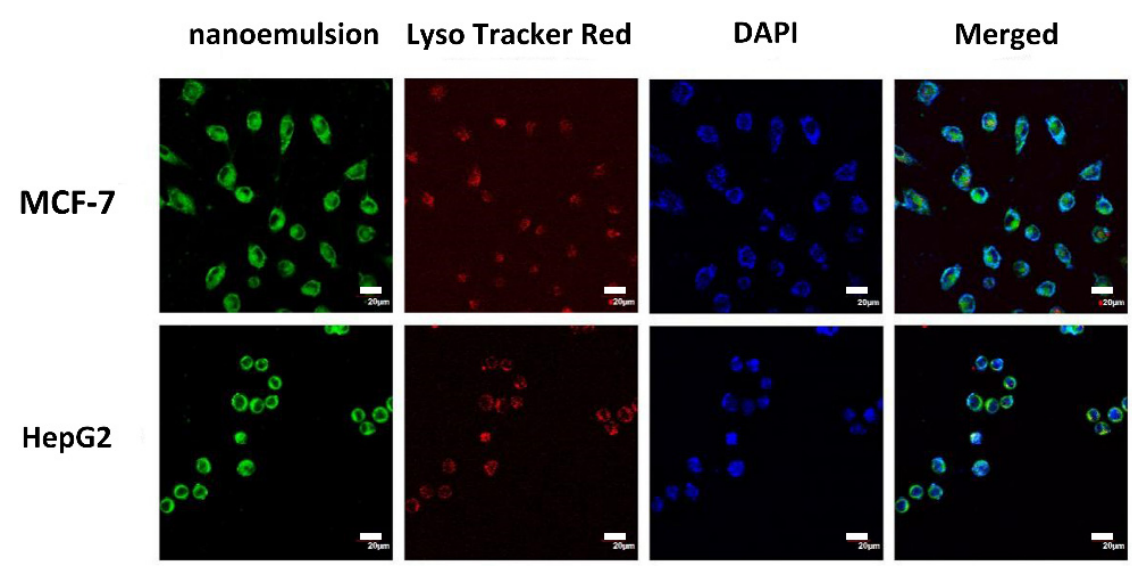

Figure 7. Cellular localization of CAS-loaded nanoemulsions after incubating with MCF-7 and HepG2 for 20 min. Nanoemulsions, lysosomes, and nuclei were labeled by coumarin-6 (first column, green color), Lyso-Tracker red (second column, red color), and DAPI (third column, blue color), respectively. The scale bar in the CLSM image is $20 \mu \mathrm{m}$. 


\subsection{Cellular Uptake Mechanism}

Cellular uptake is the process by which cells absorb molecules or materials from the extracellular space. Nanoparticles are taken into cells mainly through endocytosis [30,31], which is divided into phagocytosis and pinocytosis. Phagocytosis mainly occurs in phagocytic cells, such as fibroblasts and epithelial cells [32]. It is usually used for explaining the uptake of particles larger than $750 \mathrm{~nm}$ by mammalian cells [33,34]. Based on the protein-induced pathway, pinocytosis is subdivided into clathrin-dependent, caveolae-dependent, and macro-pinocytosis [35].

Herein, three pathway inhibitors were used to investigate some of the specific pathways involved during the cellular uptake of the casticin-loaded nanoemulsion. Dynasore inhibits dynein-dependent cellular uptake, such as clathrin-mediated and caveolae-mediated pits [36]. Chlorpromazine inhibits the transport-related molecule, resulting in the inhibition of the clathrin-mediated pathway [37]. Amiloride $\mathrm{HCl}$ dihydrate reduces the $\mathrm{pH}$ of the membrane surface to block Rac1/Cdc42 signal transmission, which induces a decrease of micropinocytosis [38]. In Figure 8a, as for MCF-7 cells, dynasore and chlorpromazine were more potent inhibitors of the casticin-loaded nanoemulsion than amiloride $\mathrm{HCl}$ dihydrate. This suggested that a clathrin-mediated pit might be the main method for the uptake of the casticin-loaded nanoemulsion into MCF-7 cells, and this might be accompanied by a small amount of macro-pinocytosis.

(a)

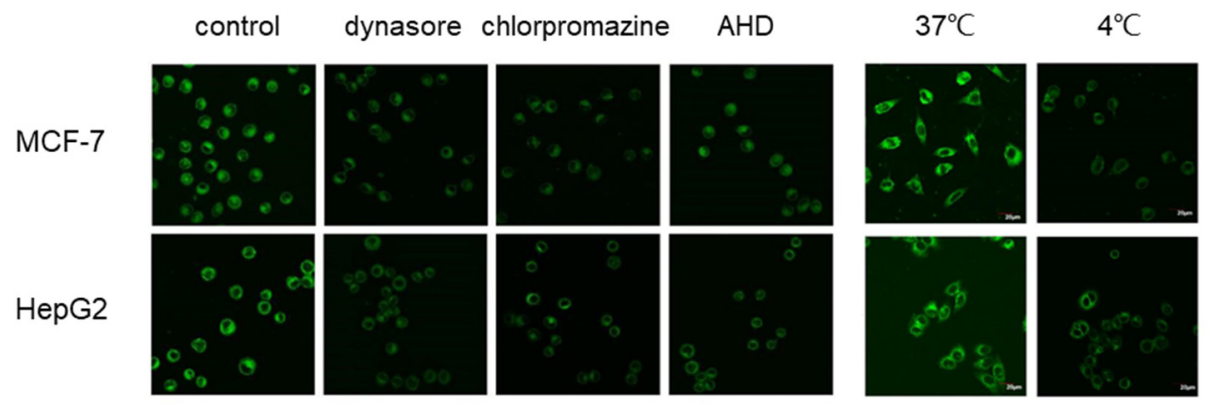

(c) (b)

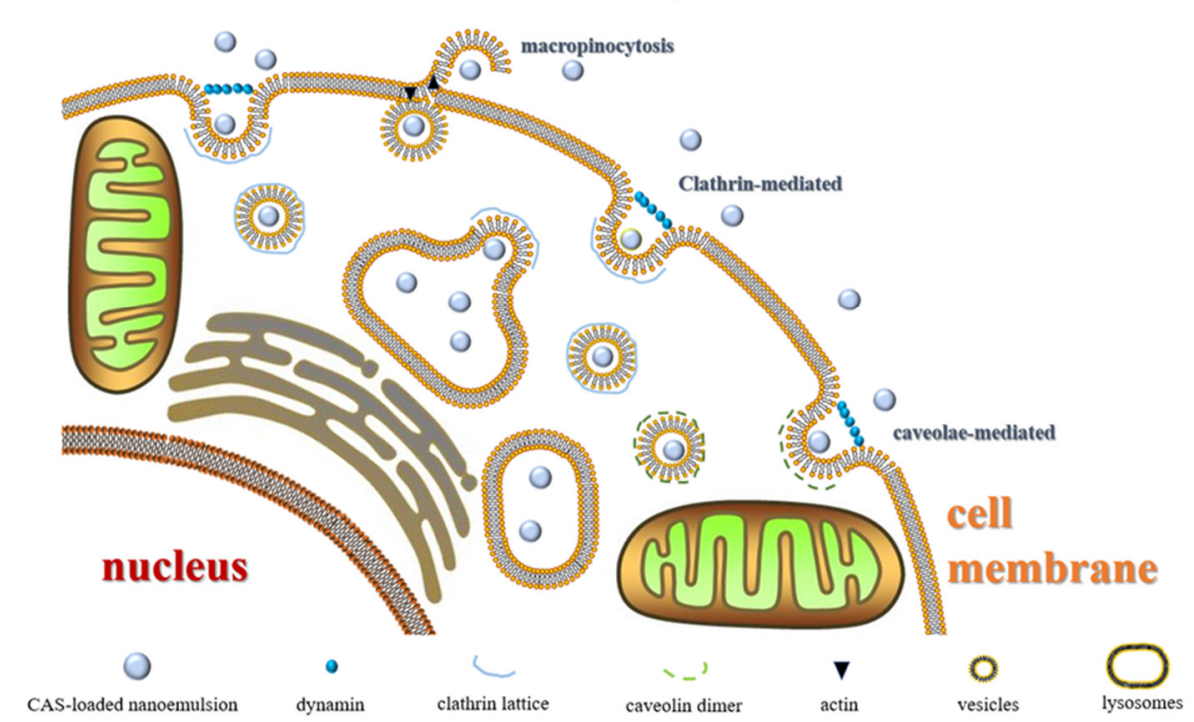

Figure 8. (a) Cellular uptakes of CAS-loaded nanoemulsions after incubating with MCF-7 and HepG2 after treatment with specific endocytosis inhibitors; (b) cellular uptake of CAS-loaded nanoemulsions after incubating with MCF-7 and HepG2 under different temperatures $\left(37^{\circ} \mathrm{C}\right.$ and $\left.4{ }^{\circ} \mathrm{C}\right)$ treatment for $30 \mathrm{~min}$. The control was incubated with nanoemulsions without inhibitors. (c) Illustration of the protentional endocytic pathways for uptake of CAS-loaded nanoemulsions. 
As for HepG2 cells, the dynasore and amiloride $\mathrm{HCl}$ dihydrate inhibitors had more influence on the cellular uptake of the casticin-loaded nanoemulsion, but chlorpromazine showed limited inhibition. Therefore, macro-pinocytosis is likely the main pathway for the entry of the casticin-loaded nanoemulsion, as well as the involvement of a small amount of clathrin-mediated and caveolae-dependent pits. The results showed a little bit of similarity to silver nanoparticles [39] and silica nanoparticles [40].

Temperature affects the entry of nanoemulsions into cells. At a low temperature, the fluidity of the cell membrane become weak, and the activity of enzymes involved in uptake activities is significantly reduced, resulting in a decrease in energy-dependent cellular uptake. As shown in Figure 8b, the MCF-7 and HepG2 cells were incubated with the casticin-loaded nanoemulsion at $37^{\circ} \mathrm{C}$ and $4{ }^{\circ} \mathrm{C}$, respectively. The low-temperature pretreatment significantly reduced the uptake of the nanoemulsion in these two cell lines. We speculated that the uptake of the casticin-loaded nanoemulsion required processes that use energy, including macro-pinocytosis, phagocytosis, and clathrin-mediated endocytosis or the use of a caveolae-dependent pit.

Figure $8 \mathrm{c}$ summarizes a partial schematic diagram of the casticin-loaded nanoemulsion entering cells through endocytosis and reaching the lysosomes. In short, there are three ways for the casticin-loaded nanoemulsion to enter the cell. The first is clathrin-mediated endocytosis. The casticin-loaded nanoemulsion reaches the cell surface, and vesicles are formed under the action of dynamin and the clathrin lattice to provide for the entry of the nanoemulsion into the cell; after that, it combines with lysosomes for degradation. The second way is through micropinocytosis. Under the action of actin, the surface of the cell membrane folds and stretches to form a groove; the nanoemulsion enters the groove during the stretching of the cell membrane and then enters the cell membrane. The third way is through the small part of a caveolae-mediated pit. Under the mediation of a dynamin and caveolin dimer, the cell membrane depression allows the casticin-loaded nanoemulsion to enter the cell. Finally, the main pathway for nanoemulsion to enter HepG2 cells is macro-pinocytosis, through which it entered MCF-7 predominantly through the clathrin-mediated pit.

\section{Conclusions}

The nanoemulsion prepared by MWPI has better stability than that prepared by WPI. The casticin-loaded nanoemulsion was fabricated by a MWPI stabilized with MCT. The loading amount of casticin in the nanoemulsion after spray-drying reached $700 \mu \mathrm{g} / \mathrm{g}$. The casticin-loaded nanoemulsion had good physical stability in the DMEM medium as its particle size was maintained at $200 \mathrm{~nm}$ over $8 \mathrm{~h}$ with a small PDI $(<0.2)$. Compared with free casticin, the casticin-loaded nanoemulsion showed a stronger inhibitory effect on MCF-7 and HepG2 cells. The inhibitory effect was dependent on the dosage of casticin and the co-culturing time. The phagocytosis of the casticin-loaded nanoemulsion by MCF-7 and HepG2 cells was time-dependent. Over time, the cellular uptake of the casticinloaded nanoemulsion increased. The casticin-loaded nanoemulsion entered the cell by co-localization with the intracellular lysosome, indicating that a portion of the casticinloaded nanoemulsion entered the cell via the lysosome. The main mechanism for the casticin-loaded nanoemulsion to enter the cells was via pinocytosis for HepG2 and clathrinmediated pits for MCF-7 cells.

Author Contributions: Conceptualization, W.J.; methodology, W.H., G.L. and W.J.; software, D.P.; formal analysis, F.J., D.P.; data curation, B.Z., M.L.; writing—original draft preparation, B.Z.; writingreview and editing, Q.H., W.J.; supervision, Q.H.; funding acquisition, Q.H. All authors have read and agreed to the published version of the manuscript.

Funding: This research was funded by the National Natural Science Foundation of China, grant number 32072152 and The APC was funded by ESI construction project of Wuhan Polytechnic University.

Acknowledgments: This work financially supported by the National Natural Science Foundation of China. 
Conflicts of Interest: The authors declare no conflict of interest.

\section{References}

1. Haidara, K.; Zamir, L.; Shi, Q.; Batist, G. The flavonoid Casticin has multiple mechanisms of tumor cytotoxicity action. Cancer Lett. 2006, 242, 180-190. [CrossRef]

2. Lee, H.; Jung, K.; Lee, H.; Park, S.; Choi, W.; Bae, H. Casticin, an active compound isolated from Vitex Fructus, ameliorates the cigarette smoke-induced acute lung inflammatory response in a murine model. Int. Immunopharmacol. 2015, 28, 1097-1101. [CrossRef]

3. Hu, Y.; Xin, H.L.; Zhang, Q.Y.; Zheng, H.C.; Rahman, K.; Qin, L.P. Anti-nociceptive and anti-hyperprolactinemia activities of Fructus Viticis and its effective fractions and chemical constituents. Phytomed. Int. J. Phytother. Phytopharm. 2007, 14, 668-674. [CrossRef] [PubMed]

4. Meng, F.; Yang, J.; Yang, C.; Jiang, Y.; Zhou, Y.; Yu, B.; Yang, H. Vitexicarpin induces apoptosis in human prostate carcinoma PC-3 cells through G2/M phase arrest. Asian Pac. J. Cancer Prev. 2012, 13, 6369-6374. [CrossRef] [PubMed]

5. Ramchandani, S.; Naz, I.; Lee, J.H.; Khan, M.R.; Ahn, K.S. An Overview of the Potential Antineoplastic Effects of Casticin. Molecules 2020, 25, 1287. [CrossRef] [PubMed]

6. Chan, E.; Wong, S.K.; Chan, H.T. Casticin from Vitex species: A short review on its anticancer and anti-inflammatory properties. J. Integr. Med. 2018, 16, 11-16. [CrossRef] [PubMed]

7. Acevedo-Fani, A.; Soliva-Fortuny, R.; Martín-Belloso, O. Nanoemulsions as edible coatings. Curr. Opin. Food Sci. 2017, 15, 43-49. [CrossRef]

8. Mcclements, D.J.; Rao, J. Food-Grade Nanoemulsions: Formulation, Fabrication, Properties, Performance, Biological Fate, and Potential Toxicity. Crit. Rev. Food Technol. 2011, 22, 285-330. [CrossRef]

9. Gao, Y.; Xie, J.; Chen, H.; Gu, S.; Zhao, R.; Shao, J.; Jia, L. Nanotechnology-based intelligent drug design for cancer metastasis treatment. Biotechnol. Adv. 2014, 32, 761-777. [CrossRef]

10. Huang, Y.; He, L.; Liu, W.; Fan, C.; Zheng, W.; Wong, Y.S.; Chen, T. Selective cellular uptake and induction of apoptosis of cancer-targeted selenium nanoparticles. Biomaterials 2013, 34, 7106-7116. [CrossRef]

11. Wei, Z.; Yang, W.; Fan, R.; Yuan, F.; Gao, Y. Evaluation of structural and functional properties of protein-EGCG complexes and their ability of stabilizing a model $\beta$-carotene emulsion. Food Hydrocoll. 2015, 45, 337-350. [CrossRef]

12. Cui, Z.; Kong, X.; Chen, Y.; Zhang, C.; Hua, Y. Effects of rutin incorporation on the physical and oxidative stability of soy protein-stabilized emulsions. Food Hydrocoll. 2014, 41, 1-9. [CrossRef]

13. Lei, L.; Zhang, Y.; He, L.; Wu, S.; Li, B.; Li, Y. Fabrication of nanoemulsion-filled alginate hydrogel to control the digestion behavior of hydrophobic nobiletin. LWT Food Sci. Technol. 2017, 82, 260-267. [CrossRef]

14. Wan, J.; Li, D.; Song, R.; Shah, B.R.; Li, B.; Li, Y. Enhancement of physical stability and bioaccessibility of tangeretin by soy protein isolate addition. Food Chem. 2017, 221, 760. [CrossRef] [PubMed]

15. Liu, G.; Li, W.; Qin, X.; Zhong, Q. Pickering emulsions stabilized by amphiphilic anisotropic nanofibrils of glycated whey proteins. Food Hydrocoll. 2019, 101, 105503. [CrossRef]

16. Mengíbar, M.; Miralles, B.; Heras, Á. Use of soluble chitosans in Maillard reaction products with $\beta$-lactoglobulin. Emulsifying and antioxidant properties. LWT Food Sci. Technol. 2017, 75, 440-446. [CrossRef]

17. Nagaraju, P.G.; Sindhu, P.; Dubey, T.; Chinnathambi, S.; Priyadarshini, C.G.P.; Rao, J.P. Influence of sodium caseinate, maltodextrin, pectin and their Maillard conjugate on the stability, in vitro release, anti-oxidant property and cell viability of eugenol-olive oil nanoemulsions. Int. J. Biol. Macromol. 2021, 183, 158-170. [CrossRef]

18. Qi, P.X.; Xiao, Y.; Wickham, E.D. Changes in physical, chemical and functional properties of whey protein isolate (WPI) and sugar beet pectin (SBP) conjugates formed by controlled dry-heating. Food Hydrocoll. 2017, 69, 86-96. [CrossRef]

19. Wang, W.D.; Li, C.; Bin, Z.; Huang, Q.; You, L.J.; Chen, C.; Fu, X.; Liu, R.H. Physicochemical properties and bioactivity of whey protein isolate-inulin conjugates obtained by Maillard reaction. Int. J. Biol. Macromol. 2020, 150, 326-335. [CrossRef]

20. Xu, D.; Wang, X.; Jiang, J.; Yuan, F.; Gao, Y. Impact of whey protein-Beet pectin conjugation on the physicochemical stability of $\beta$-carotene emulsions. Food Hydrocoll. 2012, 28, 258-266. [CrossRef]

21. Liu, G.; Wang, Q.; Hu, Z.; Cai, J.; Qin, X. Maillard-Reacted Whey Protein Isolates and Epigallocatechin Gallate Complex Enhance the Thermal Stability of the Pickering Emulsion Delivery of Curcumin. J. Agric. Food Chem. 2019, 67, 5212-5220. [CrossRef]

22. Liu, G.; Li, W.; Qin, X.; Zhong, Q. Flexible protein nanofibrils fabricated in aqueous ethanol: Physical characteristics and properties of forming emulsions of conjugated linolenic acid. Food Hydrocoll. 2021, 114, 106573. [CrossRef]

23. Huang, S.; He, J.; Cao, L.; Lin, H.; Zhong, Q. Improved Physicochemical Properties of Curcumin-Loaded Solid Lipid Nanoparticles Stabilized by Sodium Caseinate-Lactose Maillard Conjugate. J. Agric. Food Chem. 2020, 68, 7072-7081. [CrossRef]

24. Jia, C.; Cao, D.; Ji, S.; Lin, W.; Muhoza, B. Whey protein isolate conjugated with xylo-oligosaccharides via maillard reaction: Characterization, antioxidant capacity, and application for lycopene microencapsulation. LWT Food Sci. Technol. $2019,118,108837$. [CrossRef]

25. Zhang, Q.; Neoh, K.G.; Xu, L.; Lu, S.; Kang, E.T.; Mahendran, R.; Chiong, E. Functionalized mesoporous silica nanoparticles with mucoadhesive and sustained drug release properties for potential bladder cancer therapy. Langmuir 2014, 30, 6151-6161. [CrossRef] 
26. Peng, D.; Zhang, J.; Liu, Q.; Taylor, E.W. Size effect of elemental selenium nanoparticles (Nano-Se) at supranutritional levels on selenium accumulation and glutathione S-transferase activity. J. Inorg. Biochem. 2007, 101, 1457-1463. [CrossRef] [PubMed]

27. Wumaier, M.; Yao, T.; Hu, X.; Hu, Z.; Shi, S. Luminescent Ru(II)-thiols modified silver nanoparticles for lysosome targeted theranostics. Dalton Trans. 2019, 48, 10393-10397. [CrossRef]

28. Kam, N.W.S.; Dai, H. Carbon Nanotubes as Intracellular Protein Transporters: Generality and Biological Functionality. J. Am. Chem. Soc. 2005, 127, 6021-6026. [CrossRef] [PubMed]

29. Liang, L.; Li, J.; Li, Q.; Huang, Q.; Shi, J.; Yan, H.; Fan, C. Single-particle tracking and modulation of cell entry pathways of a tetrahedral DNA nanostructure in live cells. Angew. Chem. Int. Ed. Engl. 2014, 53, 7745-7750. [CrossRef] [PubMed]

30. Hu, L.; Mao, Z.; Gao, C. Colloidal particles for cellular uptake and delivery. J. Mater. Chem. 2009, 19, 3108-3115. [CrossRef]

31. Zhang, L.W.; Yang, J.; Barron, A.R.; Monteiro-Riviere, N.A. Endocytic mechanisms and toxicity of a functionalized fullerene in human cells. Toxicol. Lett. 2009, 191, 149-157. [CrossRef]

32. Hillaireau, H.; Couvreur, P. Nanocarriers' entry into the cell: Relevance to drug delivery. Cell. Mol. Life Sci. 2009, 66, 2873-2896. [CrossRef] [PubMed]

33. Zhao, F.; Zhao, Y.; Liu, Y.; Chang, X.; Chen, C.; Zhao, Y. Cellular Uptake, Intracellular Trafficking, and Cytotoxicity of Nanomaterials. Small 2011, 7, 1322-1337. [CrossRef] [PubMed]

34. Ishimoto, H.; Yanagihara, K.; Araki, N.; Mukae, H.; Sakamoto, N.; Izumikawa, K.; Seki, M.; Miyazaki, Y.; Hirakata, Y.; Mizuta, Y. Single-cell observation of phagocytosis by human blood dendritic cells. Jpn. J. Infect. Dis. 2008, 61, 294-297. [CrossRef]

35. Duncan, R.; Richardson, S.C.W. Endocytosis and intracellular trafficking as gateways for nanomedicine delivery: Opportunities and challenges. Mol. Pharm. 2012, 9, 2380. [CrossRef]

36. Macia, E.; Ehrlich, M.; Massol, R.; Boucrot, E.; Brunner, C.; Kirchhausen, T. Dynasore, a Cell-Permeable Inhibitor of Dynamin. Dev. Cell 2006, 10, 839-850. [CrossRef]

37. Chen, L.C.; Wu, C.Y.; Chen, C.F. Purification of Chlorpromazine-Sensitive GTPase From Rat Cerebral Cortex. Prep. Biochem. 1995, 25, 183-195. [CrossRef]

38. Koivusalo, M.; Welch, C.; Hayashi, H.; Scott, C.C.; Kim, M.; Alexander, T.; Touret, N.; Grinstein, H.S. Amiloride Inhibits Macropinocytosis by Lowering Submembranous $\mathrm{pH}$ and Preventing Rac1 and Cdc42 Signaling. J. Cell Biol. 2010, 188, 547-563. [CrossRef]

39. Greulich, C.; Diendorf, J.; Simon, T.; Eggeler, G.; Epple, M.; Koeller, M. Uptake and intracellular distribution of silver nanoparticles in human mesenchymal stem cells. Acta Biomater. 2011, 7, 347-354. [CrossRef] [PubMed]

40. Sun, J.; Liu, Y.; Ge, M.; Zhou, G.; Sun, W.; Liu, D.; Liang, X.J.; Zhang, J. A Distinct Endocytic Mechanism of Functionalized-Silica Nanoparticles in Breast Cancer Stem Cells. Sci. Rep. 2017, 7, 16236. [CrossRef] 